\title{
Finnish Baby Boomers and the Emergence of the Third Age
}

\author{
BY ANTTI KARISTO ${ }^{1}$
}

\begin{abstract}
This paper examines the lives of baby boomers in Finland, and is based on several studies previously published in Finnish. The article considers the particular characteristics of Finnish baby boomers. It then discusses whether the baby boom cohorts can also be called a generation. Following this, the life course of the boomer generation is contrasted with various images that have appeared in the media and elsewhere about their lives. Boomers have been presented as a "radical" or "selfish" generation. This article proposes two new themes: boomers as a crossroads generation and boomers as a bridging generation. The paper also considers the emergence of the third age as approached from a generational perspective. The third age has been defined as a generational field underpinned by agency and consumption, with its roots in the youth culture of the postwar decades. This characterization is also highly relevant to the Finnish case, but needs to be elaborated by taking into account socio-historical knowledge of the distinctive life course of the boomer generation.
\end{abstract}

Keywords: baby boomers, generations, cohorts, third age

1 Antti Karisto, Department of Social Policy, University of Helsinki, Box 18, 00014, Finland. 


\section{Introduction}

This paper examines the lives of baby boomers in Finland, and is based on several studies previously published in Finnish. The article considers first the particular characteristics of Finnish baby boomers. It then discusses whether the baby boom cohorts can also be called a generation. Following this, the life course of the boomer generation is contrasted with various images that have appeared in the media and elsewhere about their lives. Boomers have been presented, alternatively, as a "radical" or "selfish" generation. In this paper, two new themes are proposed: boomers as a crossroads generation and boomers as a bridging generation. The paper also considers the emergence of the third age as approached from a generational perspective. Gilleard and Higgs (2005; see further this issue) define third age as a generational field underpinned by agency and consumption. The authors emphasize how its roots can be traced back to the youth culture of the post-war decades. This characterization is also highly relevant to the Finnish case, but needs to be elaborated by taking into account socio-historical knowledge of the life course of the boomer generation.

\section{The Special Characteristics of Finnish Baby Boomers}

The life course of the baby boomers relates closely to the social history of Finnish society, starting from their birth. The war against the Soviet Union ended in September 1944. The war against Germany in Lapland continued, however, until the following spring, but with the majority of soldiers demobilized by the end of 1944. It then took around ten months from their home-coming for the arrival of what came to be known as the "baby boom"-generation. In the first post-war summer the birth rate more than doubled compared with previous months. It had never been as high before nor has been since. The birth rate reached its peak just after mid-August 1945, with August 24 being the most common Finnish birthday of all time (Karisto 2005b).

The meteoric increase of the birth rate is extraordinary, even taking into account the ending of the war and demobilization. It is surprising in the light of the loss of married men during the war and in the way that war-time had impeded the mating of young people. In the Finnish case, 
however, the recovery from war happened very quickly, at least from an economic, cultural and demographic perspective. By the time indemnities to the Soviet Union were paid in 1952, the country had already surpassed the pre-war gross national product (GNP). That same year was the culmination of mental reconstruction, symbolised by the Helsinki Olympic Games. The baby boom was though already over at this point, with the birth rate beginning to drop from the beginning of the 1950s (see Fig 1).

Figure 1. Number of births in Finland by the year 1940-2003.

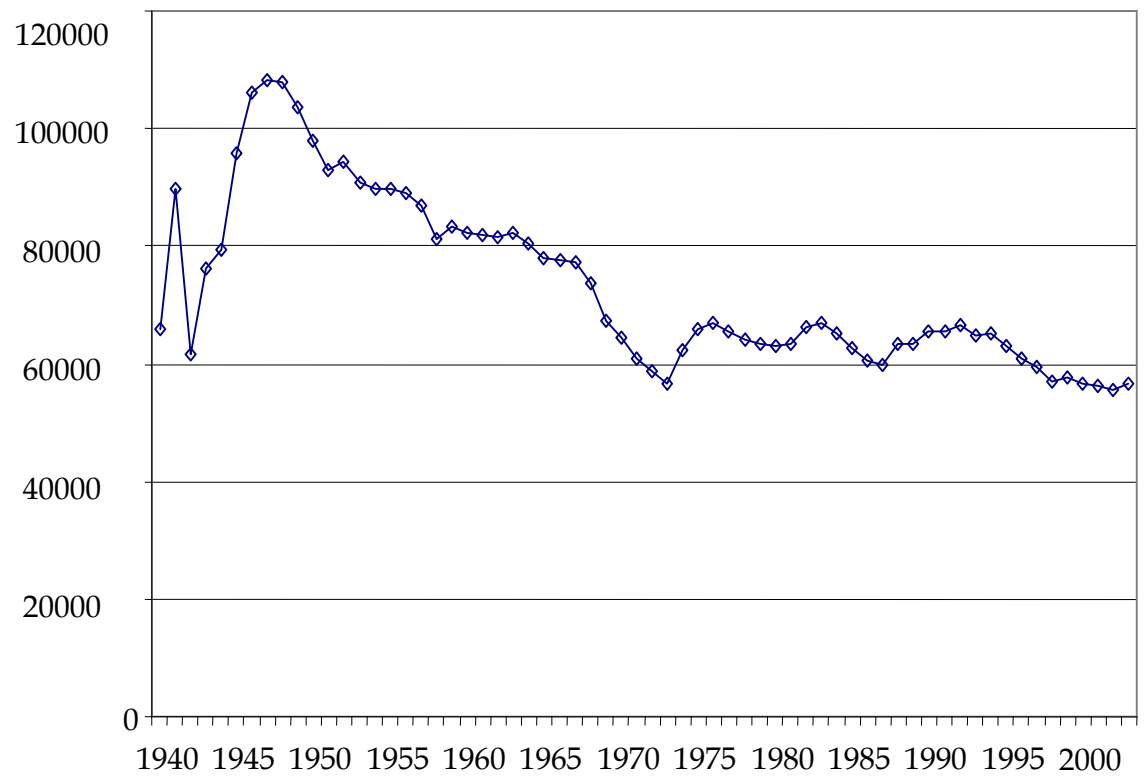

An equivalent boom took place across a range of countries following World War II, but the Finnish baby boomers appear, for a number of reasons, to be somewhat exceptional. The short-term nature of the boom has already been highlighted, with the surge in birth rates coming for a brief period in the second half of the 1940s. A second aspect concerns the size of the cohorts. Nowhere else does the relative size of these birth co- 
horts differ as much from the prior and succeeding age groups (Valkonen 1990 and 1994). In Great Britain, the annual birth rate curve of the baby boom generation climbed only about a quarter above the prior and succeeding level (Falkingham 1997); in the Finnish case it almost doubled. The third special characteristic in Finland is the lack of "an echo generation" i.e. the absence of new baby boomers. Examination of Figure 1 reveals a deep slump in the 1970s where one might have assumed that a new climb would have occurred. Moreover (in sharp contrast with many other European countries) there has been no corresponding increase in immigration to compensate for declining fertility. This has considerable significance for the labour market, where the size of the cohorts leaving employment already greatly exceeds that of those entering. Significant differences between cohorts also indicate fluctuations in service needs and in the funding of pensions.

The first two features - the size of the baby boom and its timing and span - relate to the fourth special characteristic, the generational significance of baby boomers, which is likely to differ from society to society. In Finland, the concept of baby boomers, as a sociological phenomenon, may have a greater explanatory power than for example in the United States, where the rise in the birth rate spanned the period from the mid1940s to the mid 1960s. It could be argued that the Finnish baby boom was strong enough and long enough, but yet not too long a phenomenon, so that those birth cohorts can be considered a generation of their own.

\section{From cohort to a generation}

A generation is something more than a cohort. It is "a cohort, which constitutes itself a cultural identity and as a collective one has social significance" (Edmunds and Turner 2002). The decisive factor in the formation of the generation is what happens in society during the formative years of the group concerned - an idea first expressed by Karl Mannheim (1952/1928). Many things happened when the Finnish baby boomers were coming of age. The 1960s was a decade of significant economic and social change, reflected in rapid urbanisation, cultural radicalism, the rise of the consumer society and the emergence of youth culture. The articulation of generational experiences among baby boomers was built on these various 
elements. Generational consciousness also has a tacit dimension, and a generational style appears on the level of everyday behaviour. People belonging to the same generation share all kind of everyday memories: they have read the same books, seen the same movies and television programmes, listened to the same music, and used similar clothes.

Rock music, for example, was of great importance when boomers were young. Since then it has proved to be a generational phenomenon, not simply age-related. A study of leisure activities shows how listening to rock music has now become prevalent among fifty- and sixty-year-olds (Ekholm 2005). Blue jeans are another generational icon, in which boomers have enveloped themselves ever since their days of youth. Youth in its present form was born while boomers were young, and as the first youth generation, they developed an emphatically youthful image of themselves (see, further, Biggs et al. in this issue). An equivalent "forever young" mentality, which can also prove important with the ageing of the generation, was completely unknown to the preceding generation whose youth was overshadowed by the experience of war.

Thus, the formation of the boomer generation was based upon both major social changes and minor everyday experiences. The generational consciousness or cultural identity was not born by itself but has to be produced. According to Semi Purhonen (2007), the birth of the generation requires "a discursive breakthrough", and only afterwards when this has happened can people fit their own personal experiences and memories to this articulation.

The articulation of generational experiences was not a uniform process; instead, it involved a number of competing groups. In the 1960s, when the boomer generation was born, its elite (defined in Mannheim's terms) had particular influence over generational experiences, and tried to make its own articulation generally accepted. But the elite itself (in common with most other countries) was far from homogenous. The cultural elite adopted a more or less left-wing orientation, and many of its members still identify with "the 60s generation". But it also had its opponents, another generational unit, the members of which belonged to the socio-economic elite of the society but did not share the values of the sixties. They could be called "the anti-60s generation", although they belonged to the same birth cohorts. The political turmoil did not neces- 
sarily touch the ordinary members of the baby boom cohorts who most often identify just with the "the post-war generation" or "big birth cohorts/age groups" which is the term used to describe the boomers in the Finnish language (Roos 2005; Purhonen 2007).

In spite of these internal divisions, just about every baby boomer in Finland is aware of belonging to the baby boomer generation in one way or another. This is not a trivial fact, because in many other countries boomers are primarily a phenomenon recognized by demographers and statistical experts. Although not uniform, the generational consciousness of boomers is comparatively strong, much stronger than among younger Finnish birth cohorts, even though all kinds of generational symbols have been imposed on them in public (Purhonen 2007). If any post-war cohort can be called a generation, baby boomers deserve the definition.

The Mannheimian idea that the generational consciousness is produced by the key experiences in youth implies that it tends to weaken over the course of time when memories of youth begin to diminish, but consciousness can also intensify, if it is renewed and reproduced e.g. in the media, as appears to be the case with the baby boomers. The formation of generations is fixed on time and memory from two directions: the present is read from the perspective of the past, but the past is also told from the perspective of the present (Purhonen 2007).

\section{Boomers as a Crossroads and as a Bridging Generation}

Finnish baby boomers spent their childhood in an atmosphere of postwar optimism. It was optimism of their parents, which itself had its origins in the fact that boomers were children of the men who survived the war. After the ordeals of war, there was a sense of confidence to overcome smaller obstacles (Virtanen 2001).

The life course of boomers has been influenced by different opportunities and constraints. Over three-quarters were born in rural areas, where the number of farms was still increasing, contrary to elsewhere in Western Europe. However, in the 1960s there was a significant decline in agricultural employment, along with rapid depopulation of rural areas. Whether to stay in the country or to move to the city became a major 
crossroad or divide for the members of the boomer generation (Karisto 2005b).

Over the period from 1950-1970, Finland shifted from an agricultural to an industrial and even into a post-industrial economy. In three decades, the proportion of the population employed in agriculture dropped from around 50 per cent to 15 per cent. This contrasted with Sweden where the process took five decades; in Norway where it took eight decades; and in France where it stretched over one hundred years (Karisto et al. 1998). While the previously industrialized countries had usually seen a development of the industrial labour force increasing first and the growth of the service sector following in the second phase, Finland made almost a direct transition from an agrarian pre-modern society to a "postmodern" service society (Alestalo 1986). This structural change was reflected in upward social mobility within the population. Not only industrial workers but also educated white-collar employees were needed in large numbers, and the old middle class was insufficient in size as a source of recruitment. Many baby boomers with working class or small estate farming backgrounds became secondary school graduates and in many cases proceeded to graduate from university, which was required for upper white-collar positions. Even so, elementary school remained the typical basic education in these cohorts, especially among men.

In a recent study the social and geographical mobility of baby boomers was analyzed using longitudinal data from the population census. Mobility was first examined from the inflow perspective by studying the likelihood of entering the occupational elite in the capital region (Martikainen et al. 2004). Then it was assessed from the outflow perspective by studying those who were born in the rural periphery with working class or peasant backgrounds (Karisto et al. 2005). The findings suggested that even in the context of heavy structural change, socio-economic status was a strong predictor of social mobility. Gender also played an influential role. The baby boomers were the first generation in which the level of education of women improved to a higher level in comparison with that of men. Women moved to towns more frequently compared with men, for whom staying on the rural periphery has often also meant remaining on the margins of the consumer society and also outside marriage (Karisto et al. 2005). 
The educational and occupational stratification of baby boomers was not only influenced by the role of social class. Life courses also varied greatly within families. It was quite common that only one or some of the children were put in secondary school and as a result there are many siblings among boomers, of whom some have reached almost the top of society and others have remained in blue collar professions.

Since their youth, boomers have developed an image of themselves as an avant-garde generation of transition managing and developing new social experiences. They may be seen as living in a post-industrial consumer society with many of them working in positions associated with that of the information society. They still, however, have a life-historical connection to the more traditional ethos of rural society. "We see in them a secretary of the executive group (...) or a Nokia engineer. Raittila sees in them a perplexed country boy or girl", states the cover text of author Hannu Raittila's collection of short stories (Raittila 1999). In this respect, boomers are a kind of bridging generation with links both to the past and the present. They have experience of different living surroundings, both of small farms in the sparsely populated areas as well as centers and suburbs of the cities, where the majority now live. Traces of life-historical layers of identity were found in a questionnaire survey on boomers (and older birth cohorts), which was conducted in Southern Finland (the socalled GOAL study, Good Old Age in the Lahti Region). Respondents were asked to name their favourite places, and even in the case of those living in urban areas, these were often found close to nature, and especially with men they were life-historically charged. A summer cottage and a childhood home (sometimes the same place), a sauna, a lake shore and a forest were typical answers; shopping centres, cafeterias and other urban locations were rarely mentioned (Karisto and Konttinen 2004).

Baby boomers are used to making a distinction between themselves and older cohorts. Against this, however, their own behavioural patterns sometimes resemble older cohorts. A recent Finnish study (Zacheus 2008) demonstrated their preference for traditional sports, such as crosscountry skiing, which younger cohorts have abandoned, but here again, boomers have also joined gyms and developed other new experiences in contrast to older birth cohorts. 


\section{From the Challengers of Authority to the Establishment}

American demographer Richard Easterlin (1980) has developed the thesis of "the crowded generation", a theory that suggests that large generations will experience negative effects with respect to their welfare. Large cohorts, it might be argued, do suffer from a scarcity of possibilities and resources in areas such as education, the labour market and services. Boomers in Finland do in fact have some characteristics associated with the "crowded generation" hypothesis. At the same time, they have also attracted the label "lucky generation" because they lived during the postwar economic boom when standards of living rose rapidly. They were "lucky" because they bought their houses and apartments just before the years of high inflation and rising prices. They have had fairly steady and secure working careers, and they have also benefited from the fruits of the welfare state.

Both of these contradictory hypotheses get some support from the social history of Finnish society, but are crude generalizations about the life course of the boomer generation. The same holds with the next two characteristics attached to baby boomers. Boomers have a reputation of being "a radical generation". When young they challenged those in power, and still they are considered as strong supporters of the welfare state with prevailing attitudes of solidarity to the poor and oppressed. But they are also now viewed as a selfish and conservative power block or "a stopper generation" frozen in their own power positions.

It can certainly be argued that the student radicalism at the end of the 1960s was a movement of baby boomers as was the extreme prosoviet leftism of the 1970s (Rentola 2003) - a Finnish peculiarity with no counterpart in other Western European countries. Still, the political nature of the generation has been exaggerated when the Mannheimian elite of the generation, or a part of it, has been seen as representing the entire generation. The end of the 1960s also saw the birth of the rural populist movement, which may be seen as a defensive reaction of those who stayed in the periphery and a protest against urbanization and modernisation. Besides, the politicization of the 1960s and 1970s should not be interpreted only from the viewpoint of party politics. People also learned new approaches to politicizing everyday issues, by emphasizing that many things, which may appear as self-evident, are in fact matters of 
choice. Since then this has been characteristic of new social movements, but it started in the 1960s when the dominant culture was disintegrating. Boomers were pioneers in challenging the establishment, which did not see anything political in its own attitudes, values and actions. Skilfully, boomers advanced their issues and ideas, and in this they were almost certainly helped by their size. Contrary to the earlier argument by Easterlin (1980), large birth cohorts do not always and in every case suffer from their magnitude. In public, in culture and in politics size can also be beneficial (Edmunds and Turner 2002).

If baby boomers were once the challengers of authority, today they are considered a part of the establishment, as highlighted above. According to a study of the power elite in Finland (Borg and Ruostetsaari 2002), they had clearly more representatives in various elite groups at the beginning of the new century than their impressive demographic proportion would give reason to forecast: over 40 per cent of the top members of administration, media, and industry and commerce belonged to the baby boomers, and as many as half of the leaders in labour organizations and large civil organizations were born between 1945-1950 (see Table 1).

Table 1. The percentage of the baby boomers (born between 1945-50) belonging to various elite groups in 1991 and 2001

\begin{tabular}{lcc}
\hline Group & $\begin{array}{c}1991 \\
\%\end{array}$ & $\begin{array}{c}2001 \\
\%\end{array}$ \\
\hline Politics & 29 & 26 \\
Administration & 10 & 41 \\
Industry and com- & 15 & 41 \\
merce & 19 & 51 \\
Civil organizations & 26 & 45 \\
Media & 19 & 37 \\
Science & 25 & 25 \\
Culture & 18 & 38 \\
The entire power elite &
\end{tabular}

(Borg and Ruostetsaari 2002, table 5).

The present strength of boomers' power position, however, is mainly 
explained by their present age. The power elites of the Finnish society are the same age as boomers are now - or were a few years ago. Time will soon do the job and the hold of the baby boomers on their positions of power will loosen. However, there may also be a generational effect, in addition to an age effect, behind their strong position. This is suggested by the fact that the present over-representation of boomers in the power elites is relatively larger than that of those who were 10 years older when compared with 10 years before (Borg and Ruostetsaari 2002).

Recently boomers have been attacked by members of the younger cohorts, who claim that they are a "greedy generation" which only thinks of itself in spite of claiming solidarity with those in a less fortunate position. Finnish studies examining beliefs and values across generations have in fact found only limited signs of variations across cohorts e.g. personal success is not so much valued among boomers and values associated with the welfare state are perhaps a bit more important to them than to other cohorts (Räsänen 2004; Erola 2004). First results from a survey on intergenerational transmissions (the so-called GENTRANS project) reveals that financial transmissions from baby boomers to their adult children are more common in Finland than in other European countries (Haavio-Mannila et al. 2007). This finding casts doubt on the validity of claims that boomers are "selfish" and focus only on maximising their own interests.

Attitudes, values, behaviours and life-styles of baby boomers are of particular interest now that this generation is entering retirement. By examining boomer life styles, predictions may be made as to how the role of pensioners might change in the near future. Gilleard and Higgs (2005) note that: "Past habits of consumption constrain future opportunities". They go on to suggest that: "Those who grew up spending freely earlier in life are more likely to continue to spend freely later in life". The Finnish baby boomers were not used to spending freely in their early life, but compared to older age-cohorts they are likely to be more active consumers in their retirement years. The GOAL data for example shows that people travel extensively during their retirement years. Half of those in their mid-sixties had travelled abroad during the last year, and faraway places are visited during the first retirement years more than before (Karisto and Konttinen 2004). New practices for retirement years emerged 
grown, with seasonal migration on such example (Karisto 2005a and 2008). Lifestyles such as these may become even more common when boomers reach the age of retirement.

Not only incomes but also the average value of property owned by boomers appears greater when compared with other age groups. In most cases it is homeownership, which is not easily converted into consumption. Thanks to employee pensions, the income level of pensioners has improved, but childhood memories of poverty have made older age groups careful consumers (see, also, Biggs et al. this issue). The savings ratio increases and the consumption ratio declines after retirement, contrary to what would seem likely in a situation where there is unbound purchasing power after the housing loans have been paid and children have moved away from home. New cohorts of retired people may, however, bring changes to this particular aspect of economic behaviour.

\section{Conclusion: Competing Interpretations of the Third Age}

The discussion about population ageing culminates in many ways with baby boomers and is somewhat pessimistic in its interpretation. Despite the fact that Finland has developed a reasonably coherent policy as regards population ageing (Hyvä yhteiskunta kaikenikäisille 2005), the debate is dominated by "a burden interpretation": the focus is on the pension explosion and on the care burden, which is expected to become unbearable when boomers grow old. The care burden is affected by the changes occurring in people's health and capabilities. Studies show that boomers reach retirement age healthier than previous cohorts (Sihvonen et al. 2003; Martelin et al. 2004). The so-called compression theory, suggesting that illnesses compress to the last years of life irrespective of life expectancy, have some validity. This means that the prolongation of age itself does not dramatically increase care costs.

The Finnish pension reform, which was implemented in 2005, attempts to delay the beginning of retirement and to increase the employment rate with the help of incentives: the retirement pension improves significantly if the individual stays employed past 63 years of age. In recent years, the employment rate of older workers has risen faster in comparison with other European Union countries and it is on a fairly 
high level internationally - especially bearing in mind that full-time jobs are typical of the Finnish model of employment. The retirement age will most likely still rise, because boomers are healthier than their predecessors were in the same age group.

However, the length of working careers matters as well. Because mere elementary school was the typical education of boomers, the working life for the majority began at the age of 16-17 and the working years can already now have reached over 40 . Therefore the thought of continuing working is not necessarily attractive. Much depends on how working life treats older workers. Public policies and attitudes here have contradictory features. On the one hand, individuals are told that they should continue working and that it is not appropriate to step aside to retire too soon. On the other hand, they hear that they are blocking the way for their juniors and they get blamed for low productivity and lack of innovation in society. Antti Eskola, a retired Finnish professor of sociology, expresses the issue in the following way: "Ageing workers are treated like industrial raw materials. All the profit must be squeezed out, and the final preservation of the waste must be as cheap as possible" (Eskola 1997).

The vision of a third age represents an alternative view to the burden interpretation of population ageing. The idea that the years after retirement are devoted to personal fulfilment, that one can finally do all the things one has always wanted to, is an attractive vision. It offers an alternative model on what it is like to be a pensioner. In our cultural representations, old age is going to be divided into two parts. There is an old age proper, framed by restraints, necessities and disengagement, which is described as an inevitable decline of the body and there is a third age framed by consumption possibilities, choices and opportunities, second chances and new beginnings.

One argument can certainly be advanced. The future life style of baby boomers is affected both by life choices and by life chances. The coming life of boomers cannot be imagined merely in the framework of choices and consumption. There may be financial, medical, functional and other barriers, which can transform dreams of an energetic and eventful life in retirement. Although boomers on average are relatively prosperous and can expect more active years ahead in comparison with 
earlier cohorts, socio-economic differences remain important in structuring life experiences and opportunities.

At the same time, it might be argued that third age is not only a mirage but a fact, at least demographically. ${ }^{1}$ First, the estimated life expectancy in the beginning of the retirement age has significantly improved in the recent decades, more than a year in every ten years. The life span has been prolonged at this very juncture, and most of the new retirement years are healthy years. This can be concluded from the calculations of the "healthy life expectancy", where information on mortality statistics and morbidity surveys is combined (Sihvonen et al. 2003). Secondly, in the near future there will be a great number of people reaching retirement age because of the size of the boomer cohorts. These are indisputable facts constituting the demographic frames of the third age. The third component is the emergence of the cultural dimension and is thus more uncertain. It suggests that people reach retirement age with different expectations and orientations than before and the life style of young pensioners is dissimilar from before. In this respect, the emergence of the third age depends on the choices and opportunities available to baby boomers. The first youth generation in Finland may well be also the first generation to lead a new kind of life during the pension years. Even if there was no revolution in lifestyles on the way, the small qualitative

1 There certainly is something between the middle age and old age, although I am not sure if third age is the term that captures it in the most satisfactory way. As a positive concept, it offers an alternative to "the burden interpretation", but it may even marginalize late old age, when this is seen as a negation of it. The more cheerful picture we draw on the life after the retirement, the gloomier we see the old age that does not fit into this construction. Third age is widely used in Great Britain, in France (le troisième âge) and in Spain (la tercera edad), but in Finland it is less familiar. The respondents of the GOAL survey were asked how adequate are alternative terms (third age, senior, elderly, aged, old etc.) when describing retired people and the respondents personally. None of the terms were considered really adequate (Karisto 2007). 
changes can also have a big impact, because of the quantitative cohort effect. It's now or never - as Elvis Presley, one of the favourites of first wave baby boomers - expressed it. Researching the impact of boomers on re-shaping older age is set to become an important task for social researchers in Finland.

\section{References}

Alestalo M. (1986). Structural Change, Classes and the State. Finland in a Historical and Comparative Perspective. Helsinki: Research Group for Comparative Sociology, University of Helsinki, No 33.

Borg, S. \& Ruostetsaari, I. (2002). Suuret ikäluokat ja valta [Baby boomers and power]. Hyvinvointikatsaus 2: 51-58.

Easterlin, R. A. (1980). Birth and Fortune: The Impact on Numbers on Personal Welfare. New York: Basic Books.

Edmunds, J. \& Turner, B. S. (2002). Generations, culture and society. Buckingham: Open University Press.

Ekholm, J. (2005). Musiikkivalinnat [Music choices]. In M. Liikkanen \& R. Hanifi \& U. Hannula (eds.), Yksilöllisiä valintoja ja kulttuurien pysyvyyttä. Vapaa-ajan muutokset 1981-2002 (pp. 101-116). Helsinki: Tilastokeskus.

Erola, J. (2004). Suuret ikäluokat ja solidaarisuus [Baby boomers and solidarity]. In J. Erola \& T.-A. Wilska, (eds.), Yhteiskunnan moottori vai kivireki? Suuret ikäluokat ja 1960-lukulaisuus (pp. 181-198). Jyväskylä: SoPhi.

Eskola, A. (1997). Jäähyväisluentoja [Farewell lectures]. Helsinki: Tammi.

Falkingham, J. (1997). Who are the baby boomers? A demographic profile. In M. Evandrou, (ed.), Baby boomers. Ageing in the 21 $1^{\text {st }}$ century (pp. 1540). London: Age Concern Book.

Gilleard, C. \& Higgs, P. (2005). Contexts of Ageing. Cambridge: Polity Press.

Haavio-Mannila, E. \& Roos, J. P. \& Karisto, A. \& Rotkirch, A. (2007): Intergenerational Transfers of the Finnish Baby Boomers. Paper presented in the $8^{\text {th }}$ Conference of the European Sociological Association, Glasgow, $3^{\text {rd }}-6^{\text {th }}$ September. 
Hyvä yhteiskunta kaikenikäisille. Valtioneuvoston tulevaisuusselonteko väestökehityksestä, väestöpolitiikasta ja ikärakenteen muutokseen varautumisesta [A good society for all ages. A Prime Minister's Office Report about Population Development, Population Policy and Coping with the Change of Age Structure] (2004). Helsinki: Valtioneuvoston kanslian julkaisusarja 27.

Karisto, A (2005a). Residentes Finlandeses de invierno en España. In V. Rodríguez Rodríguez \& M. A. Casado Díaz \& A. Huber (eds.): La migración de europeos retirados en España (pp. 195-220). Madrid: Consejo Superior de Investigaciones Científicas, Colección Politeya, Estudios de Política y Sociedad.

Karisto, A. (2005b). Suuret ikäluokat kuvastimessa [Baby boomers in the mirror]. In A. Karisto (ed.), Suuret ikäluokat (pp. 17-58). Tampere: Vastapaino.

Karisto, A. (2007). Seniori, vanhus vai ikäihminen - mitä nimitystä sopii käyttää? [Senior, old or ageing citizen - which is an adequate term?]. In M. Fogelholm \& I. Haapola \& P. Absetz et al. Ikihyvä Päijät-Häme tutkimus. Perusraportti 2005. Päijät-Hämeen sosiaali- ja terveysyhtymän julkaisuja 65 .

Karisto, A. (2008). Satumaa. Espanjan Aurinkorannikko suomalaiseläkeläisten talvikotina [Dreamland? Spain's Costa del Sol as a second home of Finnish pensioners]. Forthcoming.

Karisto, A. \& Takala, P. \& Haapola, I. (1998). Matkalla nykyaikaan. Elintason, elämäntavan ja sosiaalipolitiikan muutos Suomessa [Towards modern times. Living conditions, life styles and social policy in Finland]. Juva: WSOY.

Karisto, A. \& Konttinen, R. (2004). Kotiruokaa, kotikatua, kaukomatkailua. Tutkimus ikääntyvien elämäntyyleistä [Kidney pie, Emmerdale, Holidays on the Canary Islands. A study of lifestyles among the elderly]. Helsinki: Palmenia-kustannus.

Karisto, A. \& Martikainen, P. \& Mäki, N. \& Rahkonen, O. (2005). Suuren muuton pyörteissä: suurten ikäluokkien liikkuvuus ja liikkumattomuus [In the whirlpool of the great migration: the mobility and immobility of baby boomers]. In A. Karisto (ed.), Suuret ikäluokat (pp. 92114) Tampere: Vastapaino. 
Mannheim, K. (1952/1928). The Problem of Generations. In K. Mannheim, Essays on the Sociology of Knowledge (pp. 276-322). London: Routledge \& Kegan Paul.

Martelin, T. \& Sainio, P. \& Koskinen, S. (2004). Ikääntyvän väestön toimintakyvyn kehitys [The development of functional ability of ageing population]. In Ikääntyminen voimavarana. Tulevaisuusselonteon liiteraportti 5 (pp. 117-131). Helsinki: Valtioneuvoston kanslian julkaisusarja 33.

Martikainen, P. \& Mäki, N. \& Karisto, A. \& Rahkonen, O. (2004). Pääkaupunkiseudun suuriin ikäluokkiin kuuluvien ylempien toimihenkilöiden alueellinen ja ammatillinen liikkuvuus [The regional and occupational mobility of the baby boomers who belong to the occupational elite and live in the capital region]. Yhteiskuntapolitiikka 69: 31-38.

Purhonen, S. (2007). Sukupolvien ongelma. Tutkielmia sukupolven käsitteestä, sukupolvitietoisuudesta ja suurista ikäluokista [The problem of generations. Essays on the concept of generation, generational consciousness and baby boomers]. Helsinki: Research Reports No. 251, Department of Sociology, University of Helsinki.

Raittila, H. (1999). Kotia päin [Towards home]. In H. Raittila, Miesvahvuus. Proosaa (pp. 183-247). Juva: WSOY, Juva.

Rentola, K. (2003). Kevään 1968 isänmaan toivot [Fatherland's young hopefuls, spring 1968]. In S. Saaritsa \& K. Teräs (eds.), Työväen verkostot. Väki voimakas 16 (pp. 96-132). Vaasa: Työväen historian ja perinteen tutkimuksen seura.

Roos, J. P. (2005). Laajat ja suppeat sukupolvet [Broad and narrow generations]. In A. Karisto (ed.), Suuret ikäluokat (pp. 208-221). Tampere: Vastapaino.

Räsänen, P. (2004). Ikä- ja sukupolvityypillisten arvojen tarkastelua [Ageand generarionspecific values?]. In J. Erola \& T.-A. Wilska, (eds.), Yhteiskunnan moottori vai kivireki? Suuret ikäluokat ja 1960-lukulaisuus (pp. 199-214). Jyväskylä: SoPhi.

Sihvonen, A-P. \& Martelin, T. \& Koskinen, S. \& Sainio, P. \& Aromaa, A. (2003). Sairastavuus ja toimintakykyinen elinaika [Morbidity and healthy life-expectancy]. In E. Heikkinen \& T. Rantanen (eds.), Gerontologia (pp. 48-59). Helsinki: Duodecim. 
Valkonen, T. (1990). Väestönkehitys [Population development]. In O. Riihinen (ed.), Suomi 2017 (pp. 227-246). Helsinki: Keskinäinen henkivakuutusyhtiö Suomi \& Gummerus Kustannus Oy.

Valkonen, T. (1994). Työikäisen väestön vanheneminen [Ageing of working population]. In J. Kuusinen et al. (eds.), Ikääntyminen ja työ (pp. 16-26). Helsinki: WSOY \& Työterveyslaitos.

Valkonen, T. \& Kauppinen, T. M. (2005). Märkä ja nuorena nukkuva sukupolvi? [Is the wet generation drinking itself to an early grave?]. In A. Karisto (ed.), Suuret ikäluokat (pp. 334-346). Tampere: Vastapaino.

Virtanen, M. (2001). Fennomanian perilliset. Poliittiset traditiot ja sukupolvien dynamiikka [Political traditions and the dynamics of generations since the birth of the nation]. Helsinki: Suomalaisen Kirjallisuuden Seuran toimituksia 831.

Zacheus, T. (2008). Sukupolvien liikuntasuhde Suomessa [Generations' relationship to sports and physical exercise]. Forthcoming. 